M. E. Овдин, А. А. Ананин. О развитии экологического туризма на ООПТ, находящихся под управлением ФГБУ «Заповедное Подлеморье»

Научная статья

УДК 379.85:502.4

DOI 10.18101/2587-7143-2021-3-49-55

\title{
О РАЗВИТИИ ЭКОЛОГИЧЕСКОГО ТУРИЗМА НА ООПТ, НАХОДЯЩИХСЯ ПОД УПРАВЛЕНИЕМ ФГБУ «ЗАПОВЕДНОЕ ПОДЛЕМОРЬЕ»
}

\author{
(C) Овдин Михаил Евгеньевич \\ директор, Заповедное Подлеморье \\ Россия, 671623, Республика Бурятия, пос. Усть-Баргузин, ул. Ленина, 71 \\ znp.ovdin@mail.ru \\ (C) Ананин Александр Афанасьевич \\ доктор биологических наук, заместитель директора по НИР, \\ директор, Заповедное Подлеморье \\ Россия, 671623, Республика Бурятия, пос. Усть-Баргузин, ул. Ленина, 71; \\ главный научный сотрудник, \\ Институт общей и экспериментальной биологии СО РАН \\ Россия, 670047, Улан-Удэ, ул. Сахьяновой, 6 \\ a_ananin@mail.ru
}

\begin{abstract}
Аннотация. Рассматриваются вопросы организации экологического туризма на особо охраняемых природных территориях, управляемых ФГБУ «Заповедное Подлеморье» (Баргузинский государственный природный биосферный заповедник, Забайкальский национальный парк, Фролихинский государственный природный заказник). Выделены перспективные аспекты развития экологического туризма как способа сохранения природного и культурного наследия, проанализированы возможности вовлечения местного населения в экономическую деятельность, расширения образовательных аспектов туристической деятельности. В настоящее время слабое развитие рекреационной инфраструктуры подведомственных территорий не позволяет увеличивать рекреационную емкость территории, поэтому рост числа посетителей может нанести непоправимый ущерб природным комплексам. С целью снижения негативных последствий экотуризма на ООПТ можно предложить проектирование маршрутов с учетом устойчивости природных комплексов, регулирование туристических потоков, введение сезонных ограничений на посещение, создание необходимой минимальной инфраструктуры, мониторинг последствий рекреационной деятельности.
\end{abstract}

Ключевые слова: экологический туризм, Байкал, особо охраняемые природные территории, рекреационное, природоохранное, традиционное природопользование.

\section{Для цитирования}

Овдин М. Е., Ананин А. А. О развитии экологического туризма на ООПТ, находящихся под управлением ФГБУ «Заповедное Подлеморье»// Вестник Бурятского государственного университета. Биология, география. 2021. № 3. С. 49-55.

Часто экологическим туризмом ошибочно называют любое путешествие «в природу». Современное понимание термина предполагает, что экологический туризм должен быть основан на природных ресурсах и при этом не подрывать устойчивость природной среды, не наносить ей вреда, способствовать экологическому просвещению, сохранению местной социальной и культурной среды, 
обеспечению экономических выгод и устойчивого развития регионов при его осуществлении [1-4].

Основополагающей базой для организации экологического туризма в России является сеть особо охраняемых природных территорий. Особенностью туризма на ООПТ является его ориентация на экологическое просвещение и обучение посетителей. В отличие от заповедников, в которых развитие туризма может осуществляться только на специально выделенных участках (маршрутах), национальный парк предусматривает функциональное зонирование его территории. Из шести возможных зон национального парка только одна является полностью заповедной, в границах которой запрещается любое природопользование. Особо охраняемая зона национального парка уже предусматривает посещение в рамках экскурсий и познавательного туризма.

Главной отличительной чертой национального парка является наличие рекреационной зоны, в которой разрешается строительство стационарных объектов туристского сервиса (туристические гостиницы, приюты, кемпинги, визитцентры), музейных и вольерных экспозиций, необходимых объектов культурнобытового, информационного обслуживания и связи, а также объектов административно-хозяйственной инфраструктуры Учреждения. Здесь оборудуются подъездные пути, информационные площадки, автостоянки, подходы к воде, пляжи и другие элементы благоустройства. При организации рекреации на территории национального парка необходимо учитывать, что такая деятельность допускается лишь при соблюдении режима особой охраны.

Развитие экотуризма на ООПТ возможно при выполнении следующих мероприятий:

- создание необходимой туристической инфраструктуры (визит-центры, прокладка экотроп, оборудование мест отдыха, создание средств размещения и др.);

- подготовка кадров для осуществления экологического туризма среди сотрудников ООПТ;

- внедрение методики оценки экологического и рекреационного потенциала ООПТ, программ комплексного рекреационного мониторинга;

- повышение информированности потенциальных потребителей услуг экологического туризма [1].

С 1996 г. Баргузинский государственный природный биосферный заповедник, Забайкальский национальный парк, государственный природный заказник федерального значения «Фролихинский» входят в состав Центральной зоны Участка всемирного природного наследия - «Озеро Байкал», а с мая 2012 г. эти ООПТ находятся под управлением ФГБУ «Объединенная дирекция Баргузинского государственного природного биосферного заповедника и Забайкальского национального парка» («Заповедное Подлеморье»). Основной миссией, возложенной государством на Учреждение, все более становится предоставление востребованных обществом услуг в области:

- поддержания экологической стабильности территорий, в том числе существенно модифицированных хозяйственной деятельностью;

- воспроизводства в естественных условиях ценных возобновляемых природных ресурсов; 
M. E. Овдин, А. А. Ананин. О развитии экологического туризма на ООПТ, находящихся под управлением ФГБУ «Заповедное Подлеморье»

- поддержания здоровой среды для жизни людей и создания условий для развития регулируемого туризма и рекреации;

- реализации эколого-просветительских программ;

- проведения фундаментальных и прикладных исследований в сфере естественных наук.

Экосистемы Байкала, как любые северные ландшафты, обладают пониженной рекреационной устойчивостью. Природными критериями, сдерживающими массовый туризм, является высокая уязвимость экосистем, короткий сезон с комфортными климатическими условиями [5; 6]. Значительная часть территорий труднодоступна, сложна и даже опасна для массового туризма. Тем не менее с каждым годом посещаемость подведомственных территорий увеличивается (табл. 1).

Таблица 1

Сведения о количестве посетителей ООПТ, подведомственных ФГБУ «Заповедное Подлеморье»

\begin{tabular}{|c|c|c|c|c|c|}
\hline Год & $\begin{array}{c}\text { Всего по } \\
\text { территориям }\end{array}$ & $\begin{array}{c}\text { Баргузинский } \\
\text { заповедник }\end{array}$ & $\begin{array}{c}\text { Забайкальский } \\
\text { национальный } \\
\text { парк }\end{array}$ & $\begin{array}{c}\text { Фролихинский } \\
\text { заказник }\end{array}$ & $\begin{array}{c}\text { Сумма доходов } \\
\text { от туристической } \\
\text { деятельности, } \\
\text { тыс. } . \text {. }\end{array}$ \\
\hline 2018 & 43857 & 1045 & 41538 & 1274 & 13918,5 \\
\hline 2019 & 44477 & 1127 & 42399 & 951 & 19208,2 \\
\hline 2020 & 59385 & 1201 & 57230 & 954 & 21487,4 \\
\hline
\end{tabular}

Традиционно, в связи с лучшей транспортной доступностью и более высокой рекреационной емкостью, основное количество туристов посещает Забайкальский национальный парк, на территории которого отдельные участки подвергаются различной степени антропогенной трансформации под воздействием рекреационной и хозяйственной деятельности. С развитием рекреационной и туристической инфраструктуры, в том числе транспортной, следует ожидать постоянного роста интереса к озеру Байкал и, как следствие, увеличения притока посетителей.

Различный режим охраны подведомственных территорий, предусмотренный действующими положениями, определяет на них направления туристической деятельности и пути ее развития. Организация данной деятельности возложена на отдел развития туризма и рекреации. Основной задачей работы отдела является создание условий для регулируемого туризма и отдыха в природных условиях, его непосредственная организация.

К сильным сторонам туристско-рекреационной деятельности на подведомственных Учреждению ООПТ относятся:

- оз. Байкал, уникальные природные ландшафты, высокое биоразнообразие;

- слабое (контролируемое) антропогенное воздействие на охраняемые природные комплексы;

- наличие квалифицированных специалистов в области туризма и рекреации;

- взаимодействие всех структурных подразделений Учреждения в области туризма и рекреации; 
- наличие популярных туристических троп, экскурсионных маршрутов, рекреационных участков в летний и зимний сезоны;

- растущий поток посетителей.

К ее слабым сторонам следует отнести:

- недостаточно развитая туристско-рекреационная инфраструктура;

- необходимость повышения квалификации специалистов;

- короткий летний и зимний туристские сезоны, продолжительное межсезонье;

- нехватка экскурсоводов, проводников, обслуживающего персонала в разгар туристических сезонов.

На подведомственных ФГБУ «Заповедное Подлеморье» ООПТ уже существует определенная туристическая инфраструктура:

- 10 экологических троп (2 - в Баргузинском заповеднике, 6 - в Забайкальском национальном парке и 2 - во Фролихинском заказнике):

- «Шумилиха» (Баргузинский заповедник), протяженность 11 км. Тропа закрыта для посещения (после пожара 2015 г. ежегодно проводится анализ состояния тропы);

- «Давшинская бухта» (Баргузинский заповедник), общая протяженность 11,5 км. В ее состав входят 2 экологические тропы «Давша - Южный Бирикан» и «Давшинские столбы». Тропа оборудована мостками, аншлагами, смотровой площадкой и пунктом для наблюдения за медведем «Скрадок», сухим туалетом;

- «В бухту Змеиная» (Забайкальский национальный парк), протяженность 20 км. Завершено обустройство экологической тропы в бухту Змеиная, были построены причальные сооружения в местности Монахово и бухте Змеиная, обустроена стоянка автомобильного транспорта, а также смотровые площадки в местности Монахово и бухте Змеиная, создана необходимая информационная и сопутствующая инфраструктура вдоль всего полотна экологической тропы (туалеты, информационные аншлаги, скамьи, кемпинговые зоны, маркировка);

- «К лежбищу байкальской нерпы» (Забайкальский национальный парк), протяженность - 350 м. Оборудована входной группой МАФ, деревянным настилом с резиновым шумопоглощающим покрытием, лестницей, смотровой площадкой и ИЦ «Нерпа-центр»;

- «Тропа испытаний» (Забайкальский национальный парк), протяженность - 7-8 км. Оборудована входной группой МАФ, маркировкой, турами, скамьями, туалетом и спроектированным серпантином;

- «Путь к чистому Байкалу» (Забайкальский национальный парк), протяженность - 60 км. Тропа промаркирована, имеются пешеходные мосты;

- «Книга природы» (Забайкальский национальный парк), протяженность 500 м. Проведены работы по обустройству тропы, полотно тропы имеет на трех участках покрытие, расчищен коридор для дальнейшего интерпретационного наполнения;

- Кольцевая тропа «Монахово» (Забайкальский национальный парк). Имеется GPS-схема тропы, смотровая площадка, проведены исследования растительности тропы, готовятся тексты к информационным аншлагам;

- «К озеру Фролиха» (Фролихинский заказник), протяженность - 6,5 км. Оборудована входной группой МАФ, информационной аркой, стилизованным 
M. E. Овдин, A. А. Ананин. О развитии экологического туризма на ООПТ, находящихся под управлением ФГБУ «Заповедное Подлеморье»

чумом, туристическими стоянками, пешеходными мостками, гатями, лестничными подъемами, маркировкой, готовятся тексты к информационным аншлагам;

- Тропа к водопаду на р. Правая Фролиха (Фролихинский заказник), протяженность - 1 км. Имеются пешеходные мостики и лестничные подъемы;

- 11 информационных и визит-центров,

- 1 музей природы,

- 1 парковка для автомобилей,

- 260 оборудованных мест для палаточных стоянок и оборудованных мест для отдыха - «пикниковых» точек,

- 4 смотровые площадки (Ушканьи острова, бухта Змеиная, бухта Давше, Монахово),

- 5 палаточных кемпингов,

- 4 остановочных пункта для размещения (Монахово - 20 мест, Давша - 20 мест, Курбулик - 8 мест, Кабанья - 8 мест),

- 1 столовый корпус.

В 2020 г. проведено благоустройство и доукомплектование пикниковых зон и кемпингов, текущий ремонт объектов туристической инфраструктуры (60 мест отдыха), включая ремонт и покраску настилов, деревянных туалетов и стоянок, лестниц на смотровые площадки в Монахово и в бухте Змеиная, добавлены и установлены контейнеры для сбора мусора. Оборудовано 10 мест отдыха в местности Озеро Бормашовое. Завершены работы по обустройству и оборудованию экологической тропы «В бухту Змеиная», были построены туалеты, пикниковые точки, установлены навигационные знаки на протяжении тропы и в бухте Крестовая.

Установлено 4 модульных сооружения для информационных пунктов на туристических маршрутах (в бухте Змеиная, Монахово, бухте Сорожья и в местности Мягкая Карга). Проведено дополнительное обустройство кордона Южный (построено сборно-разборное брусовое сооружение для использования под баню) и кордона Монахово (текущий ремонт гостевого комплекса). Построено 4 деревянных туалета (в местности Озеро Бормашевое, в местности Вышка и на полевой базе Давша). Проведены работы по строительству экологической тропы «Книга природы» (645 м).

На визитно-информационном центре «Парк дикой природы» (при въезде на территорию национального парка) установлен демонстрационный экран с трансляцией оперативной информации об обстановке на территории Забайкальского национального парка и эколого-просветительских видеороликов для посетителей.

В 2020 г. заключено 25 договоров сотрудничества для развития туристической деятельности в ФГБУ «Заповедное Подлеморье», в том числе с физическими лицами - 13 договоров.

В настоящее время слабое развитие рекреационной инфраструктуры подведомственных территорий не позволяет увеличивать рекреационную емкость территории, поэтому рост числа посетителей может нанести непоправимый ущерб природным комплексам. С целью снижения негативных последствий экотуризма на ООПТ можно предложить проектирование маршрутов с учетом устойчивости природных комплексов, регулирование туристических потоков, введение сезон- 
ных ограничений на посещение, создание необходимой минимальной инфраструктуры, мониторинг последствий рекреационной деятельности.

Для дальнейшего эффективного развития экологического туризма и рекреации на предназначенных для этих целей участках необходимо:

- провести экспертную оценку планов развития экологического туризма и рекреации на подведомственных территориях Учреждения;

- создавать инфраструктуру для обеспечения сервисного обслуживания посетителей, в том числе путем привлечения внебюджетных средств;

- совершенствовать систему планирования, контроля и мониторинга допустимой деятельности в сфере экологического туризма и рекреации на ООПТ;

- совершенствовать комплекс экскурсионных программ для различных категорий посетителей, уделяя приоритетное внимание демонстрации диких животных в естественной среде;

- обеспечить обустройство (в том числе информационное) экскурсионных экологических троп и туристических маршрутов, смотровых площадок, мест наблюдения за дикими животными;

- совершенствовать политику сотрудничества Учреждения с представителями туристического бизнеса, осуществляющего свою деятельность на подведомственных территориях;

- повышать квалификацию специалистов, работающих с посетителями подведомственных территорий в целях экологического туризма и рекреации;

- обеспечить максимально возможную безопасность экскурсионных групп, обслуживаемых специалистами Учреждения, путем их оснащения необходимым снаряжением;

- создать необходимую материально-техническую базу рекреационного обслуживания;

- обеспечить продвижение туристического продукта Учреждения на внутренний и внешний рынок, сформировать и продвигать узнаваемый имидж Учреждения и подведомственных ООПТ;

- создавать условия для привлечения местного населения в сферу обслуживания туристов, содействовать развитию традиционных народных промыслов и производства сувениров;

- развивать партнерские отношения в области туризма с заинтересованными организациями, как в нашей стране, так и за рубежом.

\section{Литература}

1. Экологический туризм на ООПТ: состояние и проблемы / Е. И. Голубева, Н. И. Тульская, А. В. Завадская, Е. С. Каширина // Туризм и рекреация: фундаментальные и прикладные исследования: материалы ХІІ Международной конференции (25-26 апреля 2017 г.). Москва: Изд-во МГУ, 2017. С. 39-47. Текст: непосредственный.

2. Дроздов А. В. Основы экологического туризма. Москва: Гардарики, 2005. 271 с. Текст: непосредственный.

3. Завадская А. В., Яблоков В. М. Экологический туризм на особо охраняемых природных территориях Камчатского края: проблемы и перспективы. Москва: КРАСАНД, 2013. 240 с. Текст: непосредственный.

4. Чижова В. П. Концепция экологического туризма // Священными тропами Алтая: Учебно-методическое пособие по подготовке гидов-экскурсоводов. Горно-Алтайск; Барнаул: ИП С. С. Жерносенко, 2008. С. 256-260. Текст: непосредственный. 
M. E. Овдин, А. А. Ананин. О развитии экологического туризма на ООПТ, находящихся под управлением ФГБУ «Заповедное Подлеморье»

5. Ландшафтно-экологическое обоснование развития познавательного туризма в Баргузинском заповеднике / В. П. Чижова, Е. В. Бухарова, Н. И. Лозбенев [и др.] // Географический вестник. 2016. № 2(37). С. 97-109. Текст: непосредственный.

6. Рекреационная устойчивость ландшафтов Фролихинского заказника (ФГБУ «Заповедное Подлеморье») / В. П. Чижова, Е. В. Бухарова, А. Е. Разуваев, Н. М. Лужкова // Проблемы региональной экологии. 2018. № 2. С. 91-95. Текст: непосредственный.

Статья поступила в редакцию 02.09.2021; одобрена после рецензирования 06.09.2021; принята к публикации 01.10.2021.

\section{CONCERNING THE DEVELOPMENT OF ECOLOGICAL TOURISM IN PROTECTED} AREAS MANAGED BY FSBI "ZAPOVEDNOE PODLEMORYE"

Mikhail E. Ovdin

Director,

Zapovednoe Podlemorye

71 Lenina St., Ust-Barguzin 671623, Russia

znp.ovdin@mail.ru

Aleksander A. Ananin

Dr. Sci. (Biol.), Deputy Director for Science,

Zapovednoe Podlemorye

71 Lenina St., Ust-Barguzin 671623, Russia

Chief Researcher,

Institute of General and Experimental Biology SB RAS

6 Sakhyanovoy St., Ulan-Ude 670047, Russia

a ananin@mail.ru

Abstract. The article considers the issues of ecological tourism in protected areas managed by the Federal State Budgetary Institution "Zapovednoe Podlemorye" (Barguzin Nature Reserve, Zabaikalsky National Park, Frolikhinsky State Nature Sanctuary). We have revealed the promising aspects of developing ecological tourism as a way of preserving the natural and cultural heritage, analyzed the possibilities of involving the local population in economic activity, expanding the educational aspects of tourism. Currently, the poor development of the recreational infrastructure of the subordinate territories does not allow increasing the recreational capacity of the territory, so, an increase in the number of visitors can cause irreparable damage to natural complexes. In order to reduce the negative consequences of ecotourism in protected areas, we propose developing the routes with account of the sustainability of natural complexes, controlling tourist flows, introducing the seasonal restrictions on visits, creating the necessary minimum infrastructure, as well as monitoring the consequences of recreational activities.

Keywords: ecological tourism, Baikal, protected areas, recreational, environmental, and traditional natural management.

\section{For citation}

Ovdin M. E., Ananin A. A. Concerning the Development of Ecological Tourism in Protected Areas Managed by FSBI “Zapovednoe Podlemorye”. Bulletin of Buryat State University. Biology, Geography. 2021; 3: 49-55 (In Russ.).

The article was submitted 02.09.2021; approved after reviewing 06.09.2021; accepted for publication 01.10.2021. 